\title{
PERLINDUNGAN HAK CIPTA DALAM TRANSAKSI DAGANG INTERNASIONAL
}

\author{
Niken Prasetyawati*
}

\begin{abstract}
Abstrak
Globalization in commerce is an impact of advance of technology which causes global community to close and rely on another. Getting in touch in the field of economic activity requires the existence of business law harmonization across border including agreed arrangement of playing level. Applied arrangement in international commerce is GATT/WTO system.Since Indonesia ratified WTO international trade convention, this reality has placed Indonesia into point of no return potition. It meant that Indonesia mandatory to follow and comply with all arrangements prevail to all WTO's member states with its consequences, including the commitment of Intellectual Proprty Rights.
\end{abstract}

Keywords : Globalisasi perdagangan, hak cipta, karya intelektual, harmonisasi hukum.

Pada masa sekarang, siapapun menyadari kemajuan teknologi dan informasi telah memberikan kontribusi yang besar terhadap globalisasi perdagangan dan membuat masyarakat dunia semakin dekat dan saling bergantung, demikian juga dengan berbagai ciptaan-ciptaan yang termasuk hasil karya intelektual. Globalisasi perdagangan berbagai ciptaan-ciptaan tersebut memacu permintaan terhadap ciptaan -ciptaan bermutu misalnya ciptaan buku, musik, sinematografi dan program komputer dan karya-karya ilmu pengetahuan , batik ataupun kerajinan tangan yang lain. Semua ciptaan-ciptaan tersebut diperdagangkan secara cepat oleh perusahaanperusahaan multinasional secara global. Masing masing negara bersaing untuk memperebutkan pasar dunia bagi produknya. Saling bersinggungan dibidang ekonomi memerlukan harmonisasi hukum lintas negara sebagai aturan main dan kesepakatan bersama untuk perdagangan internasional. Aturan main yang diterapkan adalah aturan dari sistem GATT/WTO .

Indonesia telah meratifikasi persetujuan internasional di bidang perdagangan sistem WTO (World Trade Organization) Sebagai konsekwensinya maka Indonesia harus benar benar mematuhi semua aturan main yang ditetapkan dalam WTO dan GATT. Perdagangan karya cipta intelektual rakyat Indonesia juga akan menghadapi 
berbagai aturan aturan baru yang menghadang dalam transaksi dagang internasional karena WTO mewajibkan negara negara anggota untuk mengharmonisasikan hukum internasional yang berkaitan dengan hak kekayaan intelektual.Diundangkannya Undang-undang No.19 Tahun 2002 tentang Hak Cipta merupakan upaya peningkatan perlindungan hukum hak cipta dari peraturan perundangan sebelumnya, dengan maksud mewujudkan iklim yang lebih baik bagi tumbuh dan berkembangnya semangat mencipta dibidang ilmu pengetahuan, seni dan sastra. Lahirnya undang-undang hak cipta yang baru tidak terlepas dari kecenderungan masyarakat dunia pada umumnya dan Indonesia pada khususnya untuk memberikan perlindungan hukum Hak Kekayaan Intelektual selanjutnya disebut HKI ( Edy Damian,2002:2).

Besarnya manfaat ekonomi dari kekayaan intelektual dapat menimbulkan berbagai ketegangan dalam hubungan internasional yang diakibatkan dilanggarnya hukum HKI oleh Negara lain. Sebagai ilustrasi betapa tinggi nilai ekonomi dari HKI adalah perkara yang melibatkan Microsoft dengan suatu perusahaan kecil pembuat disket piranti lunak yang bernama Stac Electronics yang berakhir dengan kesediaan Microsoft untuk membayar ganti rugi kepada Stac Electronic sebesar US\$ 82 juta sebulan selama 43 bulan karena membajak teknologi Stac Electronic. Contoh yang lain adalah sengketa yang terjadi antara Hughes Aircraft Co. dengan pemerintah Amerika Serikat mengenai hak paten teknologi satelit, yang diputuskan Pengadilan Federal pemerintah Amerika Serikat diwajibkan membayar royalty kepada Hughes Aircraft Co. sebesar US\$ 3 miliar (Edy Damian 2002 :4).

.Hal-hal seperti ini memacu kebutuhan akan perlu ditingkatkannya perlindungan hukum terhadap pelbagai ciptaan untuk mencegah terjadinya pembajakan dan juga memberikan penghargaan terhadap suatu ciptaan sebagai suatu kekayaan intelektual. Ada beberapa faktor yang mendorong dan memberikan pengaruh yang sangat dominan terhadap usaha- usaha masyarakat internasional, termasuk Indonesia, untuk memberikan perhatian dan pengaturan Hak Kekayaan Intelektual (HKI) yang bersifat universal berdasarkan suatu perangkat hukum tentang Hak Kekayaan Intelektual yang menyeluruh dan terpadu.

\footnotetext{
* Dosen UPM Soshum ITS
} 
Di dalam Hak cipta (copyright), yang merupakan bagaian dari hak kekayaan intelektual terkandung hak- hak eksploitasi atau hak- hak ekonomi (economic rights) dan hak- hak moral (moral rights). Berdasarkan hak- hak ekonomi yang dipunyai seorang pencipta dapat mengeksploitasi suatu karya cipta sedemikian rupa untuk memperoleh keuntungan-keuntungan ekonomis, sehingga perlu untuk memperoleh perlindungan secara memadai. Adanya nilai- nilai ekonomis suatu karya cipta yang apabila tidak dikelola secara tertib berdasarkan seperangkat kaidahkaidah hukum dapat menimbulkan sengketa antara pemilik hak cipta dengan pengelola( pemegang ) hak cipta atau pihak lain yang melanggarnya. Sedangkan dengan hak moral suatu ciptaan maka seseorang mempunyai hak yang melekat, yang tidak dapat dihilangkan atau dihapus tanpa alasan apapun walaupun hak cipta tersebut atau hak terkait telah dialihkan kepada orang lain.

Upaya perlindungan HKI pada awalnya dimotori World Intellectual Property Organization / WIPO ) yang merupakan salah satu badan khusus PBB yang dibentuk di Stockholm pada tahun 1967 dan mulai efektif bekerja pada tahun 1970. Pada dasarnya ada tiga kelompok kesepakatan dasar (Treaty) yang ditangani oleh WIPO yaitu: treaty yang menetapkan standar perdagangan internasional, treaty yang memperlancar (memfasilitasi) perlindungan internasional dengan cara memberikan bimbingan atau bantuan pendaftaran atau perolehan hak dan treaty yang menetapkan sistem klasifikasi untuk membantu menejemen HKI (Rahmi Jened, $2001: 4)$.

Atas dasar keikutsertaan Indonesia dalam WTO dan persetujuan TRIPs mengharuskan Indonesia untuk turut meratifikasi Konvensi Bern dan WIPO Copyrights Treaty ( Perjanjian Internasional Hak Cipta WIPO/ selanjutnya disebut WCT) dari Organisasi Kekayaan Intelektual Dunia (World Intellectual Property Organization NIPO). Sebagai konsekwensi keikutsertaan Indonesia sebagai anggota WTO dan WIPO serta persetujuan TRIPs maka Indonesia harus mengharmonisasikan sistem HKI yang dimilikinya dengan sistem HKI yang berlaku secara internasional. Mengharmonisasikan sistem HKI bukanlah berarti sistem HKI Indonesia harus sama sepenuhnya dengan sistem HKI dinegara lain, tetapi disamakan atau diharmonisasikan adalah prinsip-prinsip dasar atau standar minimal 
sistem HKI yang sama diberlakukan dengan negara lain dan harus diterapkan di Indonesia. Dengan demikian maka penegakan dan perlindungan HKI secara umum dan hak cipta secara khusus melalui peraturan undang-undang yang dapat mengakomodasi berbagai hal diatas. Untuk itu maka perlu dikaji bagaimana perlindungan hak cipta terhadap karya cipta berdasarkan aturan undang- undang yang berlaku di Indonesia dan bagaimana pula peraturan internasional HKI yang harus diterapkan di Indonesia sebagai basis minimal.

\section{Prinsip-prinsip perlindungan hak cipta}

Karya-karya intelektual manusia adalah merupakan suatu produk olah pikir baik dibidang ilmu pengetahuan maupun seni dan sastra dan sudah sewajarnya apabila negara memberikan perlindungan terhadapnya. Hal ini sejalan dengan pemikiran yang dikemukakan oleh Arpad Bogsch,: Humans genius is the source of all work, of art and inventions. These works are guarantee of a life worthy of men. It is the duty of the state to ensure with diligence the protection of the arts and inventions. Artinya: Kecerdasan manusia adalah sumber dari semua olah pikir di bidang seni dan penemuan-penemuan. Hasil olah pikir tersebut merupakan jaminan kesejahteraan manusia. Dan itu merupakan tugas dari negara untuk memastikan sepenuhnya perlindungan ciptaan dibidang seni dan penemuan-penemuan baru (Edy Damian, 2002 :17).

Hak cipta adalah bagian dari sekumpulan hak yang dinamakan Hak-hak atas Kekayaan Intelektual, yang secara diskriptif dapat dikatakan bahwa Hak atas kekayaan intelektual adalah sebagai hak atas harta kekayaan yang merupakan produk olah pikir manusia/ kemampuan intelektual manusia. Dengan kata lain hak kekayaan intelektual adalah harta kekayaan yang timbul dari kemampuan intelektual manusia. Kekayaan seperti ini bersifat pribadi dan berbeda dari kekayaan yang timbul bukan dari kemampuan intelektual manusia, seperti hak atas :

a. Harta kekayaan yang diperoleh dari alam, yang terdiri dari : Tanah: hak milik, hak guna usaha, hak guna bangunan, hak sewa, dan lain-lain, air: hak mengelola sumber air, hak lintas damai, hak perikanan, udara: hak lintas udara maskapai penerbangan asing, hak siaran. 
b. Harta Kekayaan yang diperoleh dari benda-benda tidak bergerak dan bergerak: Hak milik atas tanah, gedung, bangunan dan rumah susun ,hak milik atas mesinmesin, hak milik atas kekayaan intelektual. hak milik atas mobil, pesawat udara , surat-surat berharga

Kata Hak Cipta terdiri dari dua kata yaitu hak dan cipta. Kata hak sering dikaitkan dengan kewajiban, adalah suatu kewenangan yang diberikan kepada pihak tertentu yang sifatnya bebas untuk digunakan atau tidak. Sedangkan kata cipta tertuju pada hasil kreasi manusia dengan menggunakan sumber daya yang ada padanya berupa pikiran, pengetahuan dan pengalaman.

Hak Cipta menurut pasal 1 ayat (1) Undang-Undang No. 19/ 2002 tentang Hak Cipta disebutkan bahwa: "Hak Cipta merupakan hak eksklusif bagi pencipta atau pemegang Hak Cipta untuk mengumumkan atau memperbanyak ciptaannya, yang timbul secara otomatis setelah suatu ciptaan dilahirkan tanpa mengurangi pembatasan menurut peraturan-peraturan perundang-undangan yang berlaku“. Sebuah bentuk ciptaan dalam bentuk tradisional seperti buku tidak akan kehilangan perlindungannya meskipun diubah kedalam bentuk digital ataupun menjadi suatu bentuk sinematografi ataupun bentuk yang lain. Dalam pembicaraan mengenai HKI sering timbul pertanyaan mengapa HKI perlu dilindungi? mungkin justifikasi yang paling mendasar oleh HKI adalah bahwa seseorang yang telah mengeluarkan usaha kedalam penciptaan sesuatu mempunyai sebuah hak alami untuk memiliki dan mengontrol apa yang mereka ciptakan. Pendekatan ini berawal dari Doktrin Hukum Alam yang menekankan pada faktor manusia dan penggunaan akal seperti yang dikenal dalam Sistem Hukum Sipil (Civil Law System) yang merupakan sistem hukum yang dipakai di Indonesia ( Satjipto Rahardjo,1990:292 ).

Teori Hukum Alam tersebut sangat berpengaruh pada negara- negara dengan sistem hukum sipil (Civil Law System) dan tampak terefleksikan dalam ketentuan pasal 27 (2) Deklarasi Hak-hak Asasi Manusia Sedunia," Setiap orang berhak untuk memperoleh perlindungan atas keuntungan-keuntungan moril maupun material yang diperoleh sebagai hasil karya ilmiah, kesusasteraan atau kesenian yang diciptakannya". Hal ini diwujudkan dengan tersedianya hak moral yang tidak dapat dicabut lagi bagi para pencipta dibanyak Negara. 
Dalam kerangka Hak Kekayaan Intelektual maka norma hukum yang mengatur tentang HKI tidak hanya terbatas pada norma hukum yang dikeluarkan dan berlaku disuatu negara tertentu, tetapi juga terikat pada norma-norma hukum internasional. Oleh karena itu negara-negara yang turut dalam kesepakatan internasional menyesuaikan peraturan dalam negaranya dengan ketentuan internasional. Indonesia termasuk salah satu negara yang turut menanda tangani Persetujuan Pembentukan Organisasi Perdagangan Dunia (Agreemant Establishing the World Trade Organization ) dan ratifikasinya telah dilakukan melalui Undangundang Nomor 7 Tahun 1994, termasuk juga Persetujuan tentang Aspek-aspek Dagang yang terkait dengan Hak Kekayaan Intelektual/TRIPs (Trade Related Aspects of IntellectualProperty Rights). Ratifikasi dari peraturan tersebut menunjang keikutsertaan Indonesia dalam Konvensi Bern, sebagaimana telah disahkan dengan Keputusan Presiden Republik Indonesia Nomor 18 Tahun 1997 tanggal 7 Mei 1997. Implikasi penanda tanganan perjanjian pembentukan WTO tersebut, Indonesia harus melakukan harmonisasi dengan ketentuan- ketentuan yang ada didalamnya. TRIPs merupakan isu baru dalam Persetujuan Umum tentang Tarif dan Perdagangan GATT (General Agreement on Tariffs and Trade) yang dimasukkan melalui Putaran Uruguay yang berjalan dari tahun 1986 sampai tahun 1994. Sebelumnya masalah HKI berada dibawah pengaturan sejumlah perjanjian multilateral yang diadministrasikan oleh forum lain, seperti WIPO, UNESCO dan UNCED ( Bambang Kesowo, 1999 :46).

Masuknya masalah HKI ke dalam GATT merupakan usulan dari negaranegara industri agar HKI mereka lebih terjamin perlindungannya dalam globalisasi perdagangan dengan alasan bahwa penyelesaian sengketa melalui GATT lebih efektif dibandingkan melalui Mahkamah Internasional seperti yang dianut oleh perjanjian-perjanjian multilateral yang lain. Dalam GATT dimungkinkan melakukan retaliation dan cross retaliation yang berupa sanksi-sanksi perdagangan yang dikenakan terhadap barang- barang ekspor negara yang melakukan pelanggaran TRIPs. Dalam persetujuan TRIPs terdapat Prinsip-Prinsip Dasar yang menjadi dasar menentukan kebijakan untuk perlindungan HKI, mengelola ataupun menegakkannya. 
Indonesia dan negara-negara anggota WIPO juga meratifikasi Perjanjian Internasional di bidang hak cipta yaitu : WIPO Copyright Treaty ( WCT) dan WIPO Performances and Phonograms Treaty (WPPT) yang merupakan perjanjian internasional WIPO yang menegaskan adanya perlindungan bagi hak cipta dan hak hak yang terkait Indonesia menjadi anggota WIPO pada tahun 1979 dengan Undang-undang No.24 tahun 1979 tentang Ratifikasi Pengesahan Organisasi Kekayaan Intelektual Dunia. WIPO didirikan berdasarkan Convention Establishing the World Intellectual Property Organization yang ditanda tangani pada 14 Juli 1976 di Stockholm. Konvensi pendirian WIPO berawal dari konvensi lain, yaitu Paris Convention for the Protection of Industrial Property, yang mulai berlaku tahun 1883 dan Berne Convention for the Protection of Literary and Artistic Works, mulai berlaku 1886. Kedua konvensi ini kemudian masing- masing mendirikan suatu International Bureau atau sekretariat. Pada tahun 1893 kedua sekretariat ini bergabung menjadi satu sekretariat dengan menggunakan nama United International Bureau for the Protection of Intellectual Property. Kemudian WIPO didirikan sebagai organisasi yang melaksanakan perlindungan hak kekayaan intelektual, WIPO menjadi organisasi khusus (specialized agency) dari PBB berdasarkan Resolusi Majelis Umum No. 3346 pada 17 Desember 1974. ( Ahmad Zen Purba,2005 :6). Namun WIPO tidak mampu melakukan adaptasi terhadap struktur perdagangan internasional dan perubahan tingkat inovasi ekonomi dan teknologi,serta tidak mempunyai mekanisme penyelasaian sengketa dan sanksi bagi para pelanggar HKI baik dari anggota maupun non anggota WIPO.

Oleh karena itu negara-negara maju mendesak agar masalah hak kekayaan intelektual langsung dikaitkan dengan perdagangan. Hal ini berarti bila suatu Negara anggota melakukan pelanggaran hak kekayaan intelektual atau peraturan nasionalnya tidak memenuhi standar yang telah digariskan secara internasional, dapat dikenai sanksi tahunan. Atas desakan tersebut maka perlindungan hak kekayaan intelektual dimasukkan kedalam agenda perundingan GATT (General Agreement on Tariffs and Trade) pada putaran Uruguay, yang merupakan putaran ke 8 negosiasi menuju kerjasama perdagangan internasional. Pada putaran ini disepakati bahwa kekayaan intelektual dapat berpengaruh terhadap perdagangan 
internasional dan pada akhir pembahasan pada Uruguay Round, Negara-Negara anggota menanda tangani Final Act Embodying the Result of the Uruguay Round of Multilateral Trade Negotiation dan juga disepakati menandatangani Agreement Establishing The World Trade Organization ( WTO Agreement) beserta lampirannya ( Annex 1,2,3, 4).

Ketentuan-ketentuan mengenai hak kekayaan intelektual diatur dalam Annex 1C yang berjudul Agreement on Trad-Related Aspects of Intellectual Property Rights. TRIPs mulai berlaku sejak 1995, suatu masa peralihan diberlakukan bagi negara-negara berkembang yang wajib memberlakukan paling lambat 4 tahun setelah itu atau awal 2000, untuk negara-negara terbelakang pemberlakuan TRIPs paling lambat awal 2006. TRIPs dalam kedudukannya bersama perjanjian multilateral lainnya yang terdapat dalam WTO Agreement adalah menunjang kelancaran perdagangan internasional. Selain itu jelas pula status hukum TRIPs dalam WTO Agreement yaitu sebagai lampiran yang merupakan kesatuan yang tidak terpisahkan serta tidak boleh ada reservations atau keberatan terhadap WTO Agreement/ TRIPs.

Hubungan kerjasama antara WIPO dan WTO dituangkan dalam Agreement between the WIPO and the WTO, 1995. Indonesia sebagai negara berkembang sudah menjadi anggota dan secara sah ikut dalam TRIPs, melalui ratifikasi WTO Agreement dengan Undang- undang No.7 tahun 1994. Ratifikasi ini kemudian dimplementasikan dalam revisi terhadap ketiga undang-undang bidang hak kekayaan intelektual yang berlaku saat itu, serta diikuti perubahan yang menyusul kemudian, serta pengundangan beberapa bidang hak kekayaan intelektual yang baru bagi Indonesia. Sehingga secara keseluruhan Indonesia telah mengundangkan beberapa perundangan baru hak kekayaan intelektual sebagai berikut: Undangundang No.29 Tahun 2000 tentang Perlindungan Varietas Tanaman, Undang-undang No.30 Tahun 2000 tentang Rahasia Dagang, Undang-undang No.31 Tahun 2000 tentang Desain Industri, Undang-undang No. 32 Tahun 2000 tentang Desain Tata Letak Sirkuit Terpadu, Undang-undang No.14 Tahun 2001 tentang Paten, Undangundang No. 15 Tahun 2001 tentang Merek, Undang- undang No. 19 Tahun 2002 tentang Hak Cipta. 
Selain mengundangkan beberapa undang- undang nasional tersebut Pemerintah Indonesia juga meratifikasi beberapa perjanjian internasional yang mengatur hak kekayaan intelektual, yaitu :Keppres No. 15 Tahun 1997 tentang Perubahan Keputusan Presiden No.24 Tahun 1979 tentang Pengesahan Paris Convention for the Protection of Industrial Property dan Convention Establishing the World Intellectual Property Organization, Keppres No. 16 Tahun 1997 tentang Pengesahan Patent Cooperation Treaty (PCT) and Regulations under the PCT, Keppres No. 17 Tahun 1997 tentang Pengesahan Trademark Law Treaty, Keppres No.18 Tahun 1997 tentang Pengesahan Bern Convention for the Protection of Literary and Artistic Works, Keppres No. 19 Tahun 1997 tentang Pengesahan WIPO copyright Treaty.

Sebagai konsekwensi keikutsertaan Indonesia meratifikasi Agreement Establishing The World Trade Organization maka dalam memberikan perlindungan pada hak cipta Indonesia mengacu pada beberapa konvensi internasional, antara lain: Konvensi Bern, WIPO Copyright Treaty TRIPs Konvensi Roma.

\section{Prinsip- prinsip Perlindungan Hak Cipta dalam Konvensi Bern}

Terdapat 10 negara peserta asli (original member)dan 7 negara yang menjadi peserta dengan cara aksesi menanda tangani naskah asli Konvensi Bern .Konvensi Bren merupakan pelopor kesepakatan internasional dibidang hak cipta .Konvensi Bern lahir pada tanggal 9 September 1886, dilengkapi di Paris 4 Mei 1896, direvisi di Berlin 13 November 1908, dilengkapi di Berne 20 Maret 1914, serta direvisi berturut turut di Roma 2 Juni 1928, di Brussels 26 Juni 1948, Stockholm 14 Juli 1967 dan Paris 29 Juli 1971 serta dirubah 28 September 1979.

Konvensi Bern merupakan konvensi tertua didunia dan sejak dibentuk hingga saat ini tercatat 150 negara yang meratifikasi. Negeri Belanda yang pada saat itu menjajah Indonesia, pada 1 November 1912 juga memberlakukan keikut sertaannya pada konvensi Bern di Indonesia berdasarkan asas konkordansi. Dengan kata lain Indonesia semenjak 1912 telah mempunyai Undang-undang Hak Cipta (Auteurswet)berdasarkan Undang-undang Belanda tanggal 29 Juni 1911 ( Staatsblad Belanda Nomer 197 )yang memberikan wewenang kepada Ratu Belanda untuk 
memberlakukan bagi negara Belanda sendiri dan negara-negara jajahannya Konvensi Bern 1886 berikut revisi pada 13 November 1908 di Berlin. Indonesia pernah keluar dari anggota Konvensi Bern pada tahun 1958 dan kemudian masuk kembali pada tanggal 5 September 1997 melalui Keppres No. 18 Tahun 1997. Konvensi Bern 1886 pada garis besarnya memuat 3 prinsip dasar, berupa suatu kumpulan ketentuan yang mengatur standar minimum perlindungan hukum (minimum standard of protection )yang diberikan kepada pencipta dan juga memuat ketentuan yang berlaku khusus bagi Negara berkembang. 3 prinsip dasar yang dianut Konvensi Bern, yaitu:

1. Prinsip National Treatment : Ciptaan yang berasal dari salah satu Negara peserta perjanjia, ciptaan seorang warga negara, negara peserta perjanjian, atau suatu ciptaan yang pertama kali diterbitkan disalah satu Negara peserta perjanjian, harus mendapat perlindungan hukum hak cipta yang sama seperti yang diperoleh ciptaan seorang pencipta warga negara sendiri.

2. Prinsip Automatic Protection: Pemberian perlindungan hukum harus diberikan secara langsung tanpa harus memenuhi syarat apapun ( must not be conditional upon compliance with any formality ).

3. Prinsip independence of protection: Suatu perlindungan hukum diberikan tanpa harus bergantung kepada pengaturan perlindungan hukum negara asal pencipta.

Standar minimum yang berlaku mengenai jangka waktu berlakunya perlindungan hukum hak cipta, Konvensi Bern menentukan sebagai ketentuan umum: selama hidup pencipta ditambah 50 tahun setelah pencipta meninggal. Meskipun demikian tidak tertutup pengecualian pengecualian . Perlindungan hukum hak cipta atas ciptaan yang tidak diketahui penciptanya (anonymous) atau pencipta yang memakai nama samaran (pseudonymous) maka perlindungan hukum hak ciptanya adalah 50 tahun semenjak pengumumannya secara sah dilakukan .

Konvensi Bern juga mengatur jangka waktu perlindungan hukum ciptaan ciptaan audiovisual ( Cinematographic ), jangka waktu perlindungan minimumnya adalah 50 tahun sejak ciptaan direkam dan dapat diperoleh konsumen, jika tidak direkam dan tidak dapat diperoleh konsumen, perlindungan hukumnya adalah minimum 50 tahun semenjak diciptakan. Sedangkan untuk ciptaan ciptaan yang 
tergolong seni terapan dan fotografi, jangka waktu perlindungan adalah 25 tahun sejak diciptakan.

\section{Prinsip prinsip perlindungan Hak Cipta dalam WIPO Copyright Treaty.}

Dalam WIPO Copyright Treaty yang diratifikasi oleh Indonesia melalui Keppres No. 19 Tahun 1997 tentang Pengesahan WIPO Copyright Treaty, terdapat 25 pasal dan didalamnya terdapat pernyataan kesepakatan Konferensi Diplomatik yang mengadopsi Traktat dan Ketentuan ketentuan Konvensi Bern (1971) seperti yang terdapat dalam traktat ini. Dengan melihat isi dari WIPO Copyright Treaty maka untuk perlindungan Hak Cipta pada pokoknya tetap mengacu pada Konvensi Bern seperti yang terdapat dalam lampiran treaty ini .

\section{Prinsip prinsip perlindungan hak cipta dalam TRIPs}

TRIPs memuat ketentuan ketentuan substantif minimal yang harus diikuti oleh Negara Negara anggotanya, ini berarti TRIPs juga secara substantive menyumbang pada perkembangan sistem hak kekayaan intelektual internasional disamping juga merujuk substansi yang terdapat dalam berbagai konvensi atau perjanjian internasional.

Sebagaimana halnya perjanjian multilateral lainnya TRIPs juga memiliki ketentuan dan prinsip prinsip dasar bagi para anggotanya dalam melaksanakan aturannya. Ketentuan ketentuan dan prinsip dasar tersebut tertuang dalam Bab I pasal 1s/d 8. Ketentuan ketentuan dan prinsip prinsip dasar tersebut, antara lain adalah:

1. Ketentuan Free to Determine yaitu ketentuan yang memberikan kebebasan kepada para anggotanya untuk menentukan cara yang dianggap sesuai untuk menerapkan ketentuan ketentuan yang tercantum dalam TRIPs kedalam system dan praktek hukum mereka.

2. Ketentuan Intellectual Property Convention yaitu ketentuan yang mengharuskan para anggotanya menyesuaikan peraturan perundangannya dengan berbagai konvensi internasional di bidang hak Milik Intelektual, khususnya Konvensi 
Paris, Konvensi Bren, Konvensi Roma, dan Treaty on Intellectual Property in Respect of Integrated Circuit

3. Ketentuan National Treatment yaitu ketentuan yang mengharuskan para anggotanya memberikan perlindungan hak milik intelektual yang sama antara warga negaranya sendiri dengan warga Negara lain, dan juga untuk badan badan hukum.

4. Ketentuan Most Favoured Nation Treatment.yaitu ketentuan yang mengharuskan para anggotanya memberikan perlindungan yang sama terhadap seluruh anggotanya, untuk menghindarkan perlakuan istimewa yang berbeda (diskriminasi) suatu Negara terhadap Negara lain.

5. Ketentuan Exhaution yaitu ketentuan ini mengharuskan para anggotanya dalam menyelesaikan sengketa, untuk tidak menggunakan suatu ketentuanpun didalam persetujuan TRIPs sebagai alasan tidak optimalnya pengaturan Hak Milik Intelektual dalam Negara mereka.

\section{Prinsip prinsip perlindungan hak cipta dalam Konvensi Roma.}

Dalam rangka untuk lebih memajukan perlindungan hak cipta diseluruh dunia, khususnya perlindungan hukum internasional terhadap mereka yang dikelompokkan dengan nama hak hak terkait. Pembahasan pertama kali pada tingkat internasional tentang hak hak yang terkait terjadi pada tahun 1928. Pada konferensi internasional yang membicarakan revisi Konvensi Bern di Roma, suatu rekomendasi dikemukakan oleh Negara Negara peserta Bern Union yang berkeinginan untuk mengatur perlindungan hak hak para pelaku artis ( performing artist). Setelah melaui berbagai perundingan, akhirnya pada tahun 1961 berhasil ditanda tangani suatu perjanjian internasional di Roma : Convention for the Protection of Performers, Producers of Phonogram and Broadcasting Organization. Konvensi ini sering disebut sebagai Rome Convention.

Maksud tujuan utama dari diadakannya konvensi ini adalah menetapkan pengaturan secara internasional perlindungan hukum terhadap tiga kelompok pemegang hak cipta atas hak hak terkait yaitu: Artis-artis pelaku (performing artists) yang dapat terdiri misanya, penyanyi, actor, musisi, penari, dan lain lain, Produser 
produser rekaman (Producers of Phonogram). Lembaga lembaga penyiaran (Broadcasting Organization). Pengadministrasian dari Konvensi Roma dilakukan secara terpadu oleh ILO, UNESCO dan WIPO, ketiga organisasi ini mendirikan suatu sekretariat antar pemerintah Negara anggota.

\section{Prinsip-prinsip Perlindungan Hak Cipta menurut Undang-undang No.19 Tahun 2002}

Perjalanan perlindungan hukum terhadap karya cipta di Indonesia dimulai dengan Auteurswet 191Staatsblad 1912 No.600 yang berlaku di Indonesia berdasarkan asas konkordansi sebagai jajahan Belanda, kemudian Undang-undang No.6 Tahun 1982, Undang-undang No.7 Tahun 1987. Undang-undang No.12 Tahun 1997, dan sekarang Undang-undang No.19 Tahun 2002

Perkembangan terakhir terhadap hak cipta, ada beberapa pertimbangan yaitu, keikutsertaan Indonesia dalam Persetujuan Pembentukan Organisasi Perdagangan Dunia (Agreement Establishing the World Trade Organization) yang didalamnya tercakup Persetujuan tentang Aspek-aspek Dagang Hak Atas Kekayaan Intelektual (Agreementon Trade Related Aspect of Intellectual Property Rights/ TRIPs)dan salah satu pengaturannya mengenai hak cipta dan hak-hak terkait.Disamping itu Indonesia juga telah meratifikasi Konvensi Bern dan WIPO Copyrights Treaty.Oleh karena itu Indonesia berkewajiban untuk menyesuaikan undang-undang nasional di bidang hak cipta dan hak terkait sehingga dapat menampung perkembangan tersebut. Undang-Undang No. 19 tahun 2002 memuat beberapa ketentuan baru, antara lain mengenai:

a. Database nerupakan salah satu ciptaan yang dilindungi

b. Penggunaan alat apapun baik melalui kabel maupun tanpa kabel, termasuk media internet, untuk pemutaran produk-produk cakram optic melalui media audio, media audiovisual dan atau sarana telekomunikasi

c. Penyelesaian sengketa oleh Pengadilan Niaga, arbitrase atau alternative penyelesaian sengketa

d. Penetapan sementara pengadilan untuk mencegah kerugian yang lebih besar bagi pemegang hak 
e. Batas waktu proses perdata di bidang hak cipta dan hak terkait baik di Pengadilan Niaga maupun di Mahkamah Agung

f. Pencantuman hak informasi menejemen elektronik dan sarana kontrol teknologi

g. Pencantuman mekanisme pengawasan dan perlindungan terhadap produk-produk yang menggunakan sarana produksi berteknologi tinggi

h. Ancaman pidana atas pelanggaran hak terkait

i. Ancaman pidana dan denda minimal

j. Ancaman pidana terhadap perbanyakan penggunaan program computer untuk kepentingan komersial secara tidak sah dan melawan hukum

Dari perkembangan perlindungan hukum hak cipta, dapat dilihat usaha pemerintah Indonesia untuk memberikan perlindungan bagi para pencipta kekayaan intelektual guna semakin menumbuhkan minat dan kreasi untuk terus mencipta. Adapun prinsip-prinsip perlindungan hak cipta yang terdapat dalam Undang-Undang No.19 tahun 2002 tentang Hak Cipta dapat diuraikan sebagai berikut :

Dalam pasal 1 angka 1 Undang-Undang Hak Cipta 2002 hak cipta disebutkan sebagai berikut: Hak Cipta adalah hak eksklusif bagi pencipta atau penerima hak untuk mengumumkan atau memperbanyak ciptaannya atau memberikan izin untuk itu dengan tidak mengurangi pembatasan-pembatasan menurut peraturan perundang-undangan yang berlaku.

Dari rumusan pasal tersebut pencipta atau pemegang hak cipta mempunyai hak ekslusif untuk: Mengumumkan ciptaannya memperbanyak ciptaannya memberikan izin untuk mengumumkan atau memperbanyak ciptaannya. Sedangkan hak ekslusif sendiri diartikan sebagai hak yang semata-mata diperuntukkan bagi pemegangnya sehingga tidak ada pihak lain yang boleh memanfaatkan hak tersebut tanpa izin pemegangnya( penjelasan pasal 2 ayat 1 ).

Dalam pasal 1 angka 2 disebutkan pencipta adalah :

Seorang atau beberapa orang secara bersama-sama yang atas inspirasinya lahir suatu ciptaan berdasarkan kemampuan pikiran, imajinasi, kecekatan, ketrampilan, atau keahlian yang dituangkan dalam bentuk yang khas dan bersifat pribadi. 
Dalam pasal 12 Undang-Undang Hak Cipta 2002 ciptaan yang dilindungi adalah sebagai berikut:

a Buku, program komputer, pampflet, perwajahan (lay out) karya tulis yang diterbitkan , dan semua hasil karya tulis lain .

b Ceramah, kuliah, pidato, dan ciptaan lain yang sejenis dengan itu.

c Alat peraga yang dibuat untuk kepentingan pendidikan dan ilmu pengetahuan.

d Lagu atau musik dengan atau tanpa teks.

e Drama atau drama musical, tari, koreografi, pewayangan dan pantomime.

f Seni rupa dalam segala bentuk seperti seni lukis, gambar, seni ukir, seni kaligrafi, seni pahat, seni patung dan seni terapan.

g Arsitektur.

h Peta.

i Seni batik.

j Fotografi.

k Sinematografi.

1 Terjemahan, tafsir, saduran, bunga rampai, data-base, dan karya lain hasil pengalihwujudan.

Ciptaan sebagaimana dimaksud dalam huruf 1 juga dilindungi sebagai ciptaan tersendiri dengan tidak mengurangi hak cipta atas ciptaan asli.

Jangka waktu perlindungan hukum untuk suatu ciptaan ditentukan berlaku selama hidup pencipta dan terus berlangsung hingga 50 tahun setelah pencipta meninggal. Jika ciptaan dimiliki oleh 2 orang atau lebih, hak cipta berlaku seumur hidup pencipta yang meninggal paling akhir dan berlangsung 50 tahun sesudahnya, dan jika ciptaan dimiliki oleh suatu badan hukum maka berlaku selama 50 tahun sejak pertama kali diumumkan.

Menurut pasal 10 ayat (1) dan ayat (2) serta pasal 11 ayat(1) dan ayat (3) Undang-Undang Hak Cipta 2002, Negara adalah sebagai pemegang hak cipta atas : ciptaan peninggalan pra sejarah, sejarah dan bentuk budaya nasional lainnya, dan ciptaan hasil kebudayaan rakyat yang menjadi milik bersama, seperti cerita hikayat, dongeng, legenda, babad, lagu, kerajinan tangan, koreografi, tarian, kaligrafi dan karya seni lainnya.Jangka waktu perlindungan hukumnya adalah tanpa batas waktu. 
Ciptaan yang tidak diketahui penciptanya dan ciptaan itu belum diterbitkan atau jika suatu ciptaan sudah diterbitkan tetapi tidak diketahui nama penciptanya dan penerbitnya maka jangka waktu perlindungannya adalah 50 tahun sejak ciptaan itu diketahui umum, untuk ciptaan yang telah diterbitkan tetapi tidak diketahui penciptanya atau hanya tertera nama samaran, maka hak cipta dilaksanakan oleh penerbit berlaku selama 50 tahun sejak ciptaan pertama kali diterbitkan.

Jangka waktu perlindungan hak cipta atas ciptaan yang diumumkan bagian demi bagian, dihitung mulai tanggal pengumuman bagian terakhir, dalam menentukan jangka waktu berlakunya hak cipta atas ciptaan yang terdiri atas 2 jilid atau lebih, demikian pula ikhtisar dan berita yang diumumkan secara berkala dan tidak bersamaan waktunya, setiap jilid atau ikhtisar dan berita itu masing-masing dianggap ciptaan tersendiri.

Sebagai hak moral, pencipta atau ahli warisnya berhak menuntut pemegang hak cipta supaya nama pencipta dicantumkan tanpa batas waktu. Walaupun hak ciptanya telah diserahkan kepada pihak lain, kecuali dengan persetujuan pencipta atau ahli warisnya dalam hal pencipta sudah meninggal, suatu ciptaan tidak boleh diubah termasuk juga terhadap perubahan judul dan anak judul ciptaan, pencantuman nama atau nama samaran pencipta mendapat perlindungan hukum yang berlaku selama berlangsungnya jangka waktu hak cipta atas ciptaan yang bersangkutan, kecuali untum pencantuman dan perubahan nama atau nama samaran penciptanya.

Penyelenggaraan administrasi Hak Cipta dilaksanakan oleh Direktorat Jenderal yang menyelenggarakan system jaringan dokumentasi dan informasi Hak Cipta yang bersifat nasional. Apabila timbul sengketa di bidang hak cipta maka penyelesaian sengketa tidak hanya dapat diselesaikan secara perdata dengan memajukan gugatan ganti rugi kepada Pengadilan Niaga atau melalui lembaga arbitrase atau alternative penyelesaian sengketa saja, tetapi juga dapat diselesaikan secara pidana, apabila sengketa hak cipta diselesaikan secara pidana maka pemegang hak cipta harus melaporkan pelanggaran hak cipta yang dialaminya melalui penyidik polisi atau PPNS. 
Penetapan sementara pengadilan dilakukan oleh Pengadilan Niaga atas permintaan pemohon yang hak ciptanya dilanggar oleh pihak lain,untuk mencegah kerugian lebih lanjut, serta menimbulkan "efek kejut " bagi pelanggar agar tidak melanjutkan pelanggarannya. Selama ini upaya penetapan sementara Pengadilan merupakan upaya hukum yang cukup efektif dan represif awal untuk melindungi para pencipta atau pemegang hak..

\section{Kesimpulan}

Dalam perdagangan internasional negara negara baik yang tergabung dalam Konvensi Bern maupun dalam WTO ataupun TRIP's berusaha mengakomodir kemajuan teknologi agar perlindungan kekayaan intelektual bisa dilakukan secara maksimal karena hal ini akan berdampak besar bagi kreatifitas pencipta yang dilindungi oleh negara.

Indonesia memberikan perlindungan tersebut dengan mengharmonisasikan aturan aturan yang berkaitan dengan perlindungan hak kekayaan intelektual, sesuai kesepakatan dan ratifikasi yang dilakukan oleh pemerintah dengan negara lain.

\section{Daftar Pustaka}

Achmad Zen Umar Purba,Hak Kekayaan Intelektual Pasca TRIPs, Alumni, Bandung, 2005

Ahmad M. Ramli, Cyberlaw dan HAKI dalam Sistem Hukum Indonesia, Rafika aditama Bandun, 2004.

Bambang Kesowo, GATT, TRIPs dan Hak Kekayaan Intelektual, Mahkamah Agung, 1998

Budi Agus Riswandi dan M Syamsudin, Hak Kekayaan Intelektual dan Budaya Hukum, Raja Grafindo Persada, Jakarta, 2004.

Edy Damian, Hukum Hak Cipta, Alumni, Bandung, 2004.

H.S. Kartadoemena, GATT dan WTO Sistem, Forum dan Lembaga Internasional dibidang Perdagangan, UI Press, 2002.

Nandang Sutrisno, Implementasi Persetujuan TRIPs dalam Undang- undang Hak Cipta Indonesia, Jurnal Hukum No.12 Volume 6, 1999. 
O.K Saidi, Aspek Hukum Kekayaan Intelektual, Raja Grafindo Persada, Jakarta, 2004.

Rahmi Jened, Perlindungan Hak Cipta Pasca Persetujuan TRIPs, Yuridika Press, Fakultas Hukum Universitas Airlangga , 2001.

Satjipto Rahardjo, Ilmu Hukum, Alumni, Bandung, 1990.

Siaran IKAPI No. 04 / Tahun II , April- Mei 1999.

Sudargo Gautama, Rizawanto Winata , Konvensi- konvensi Hak Intelektual Baru untuk Indonesia, Citra Aditya Bakti, Bandung, 1997.

Tim Linsey, Edy Damian dkk , Hak Kekayaan Intelektual Suatu Pengantar, Alumni, Bandung, 2003.

Kompilasi Undang- undang Hak Cipta, Paten, Merek dan Terjemahan Konvensikonvensi dibidang Hak Kekayaan Intelektual, Seri A dan Seri B, Citra Aditya Bakti Bandung, 2004. 